\title{
A radical approach to diagnosing infection
}

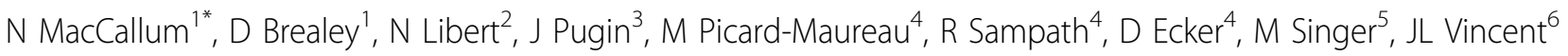 \\ From ESICM LIVES 2015 \\ Berlin, Germany. 3-7 October 2015
}

\section{Introduction}

The cornerstone of sepsis management requires identifying the causative pathogen and initiating appropriate antimicrobial therapy. Current pathogen detection relies on culture techniques, a technology that is over 100 years old, slow and unreliably. It is not unusual for only $10 \%$ of critical care blood cultures to be positive. Due to the low yield and time taken to obtain a result, they rarely alter patient management. A novel molecular pathogen detection system, known as IRIDICA, employs polymerase chain reaction and electro spray ionisation mass spectroscopy (PCR/ESI-MS) to identify over 1000 pathogens, direct from sample without culture and within 8 hours. The RADICAL study was created to assess this technology in a real world critical care environment.

\section{Objectives}

To compare the PCR/ESI-MS rapid pathogen detection system to hospital standard of care microbiology techniques.

\section{Methods}

RADICAL was a multi-centre, prospective, cohort observational trial involving 9 European Critical Care Units. Critically ill patients having standard of care microbiology samples, for the investigation of potential sepsis (such as blood culture or endotracheal aspirate etc.), had a simultaneous sample for PCR/ESI-MS analysis. The sample was frozen and later analysed and results were compared to those obtained from the hospital laboratory. Although treating clinicians were blinded to the results, an independent panel of doctors reviewed the results as to whether they would have altered antibiotic prescribing.

\section{Results}

543 patients were recruited between 2013-2014. 616 paired blood samples, 179 deep respiratory tract samples

${ }^{1}$ University College London Hospitals, London, United Kingdom

Full list of author information is available at the end of the article and 110 samples from other sterile sites (e.g. CSF) were obtained. A pathogen was detected by blood culture in $67(11 \%)$ samples and in $223(33 \%)$ samples by PCR/ ESI-MS. The pathogens isolated by both techniques were those expected in the critical care environment, E. coli and S.aureas being the most frequent. The performance characteristics (Table 1) demonstrated the PCR/ESI-MS result at 8 hours had a negative predictive value of $97 \%$.

169 patients also had replicate blood sampling; PCR/ ESI-MS was concordant in $85 \%$ of cases, culture in $55 \%$. Relative yields from the PCR/ESI-MS were smaller for respiratory and other samples but still superior to culture and obtained within 8 hours.

The independent panel reviewed 442 case forms and concluded that the PCR/ESI-MS result could have altered antibiotic prescribing in $42 \%$ of cases, rising to $57 \%$ if the result was positive.

\section{Conclusions}

PCR/ESI-MS performs well with numerous sample types. It is 3 times more likely to identify a pathogen in blood compared to standard culture but also carries a high negative predictive value. The PCR/ESI-MS is capable of obtaining these results within 8 hours compared to an average of 48 hours for culture. This information may be invaluable in rapidly guiding antibiotic prescribing and aiding stewardship.

\section{Grant Acknowledgment}

RADICAL study funded by Abbott.

Table 1. PCR/ESI-MS performance vs blood culture

\begin{tabular}{ccccc}
\hline \multicolumn{5}{c}{ CULTURE } \\
\hline PCR/ESI-MS & POSITIVE & 54 & 169 & $223(36 \%)$ \\
\hline & NEGATIVE & 13 & 380 & $393(64 \%)$ \\
\hline & TOTAL & $67(11 \%)$ & $549(89 \%)$ & 616 \\
\hline
\end{tabular}




\section{Authors' details}

${ }^{1}$ University College London Hospitals, London, United Kingdom. ${ }^{2}$ Military Hospital du Val-de-Grace, Paris, France. ${ }^{3}$ Hopitaux Universitaires de Geneve, Geneva, Switzerland. ${ }^{4}$ bis Biosciences Abbott, Carlsbad, United States.

${ }^{5}$ University College London, London, United Kingdom. ${ }^{6}$ Erasme University Hospital, Bruxelles, Belgium.

Published: 1 October 2015

doi:10.1186/2197-425X-3-S1-A4

Cite this article as: MacCallum et al:. A radical approach to diagnosing

infection. Intensive Care Medicine Experimental 2015 3(Suppl 1):A4.

\section{Submit your manuscript to a SpringerOpen ${ }^{\mathcal{D}}$ journal and benefit from:}

- Convenient online submission

- Rigorous peer review

- Immediate publication on acceptance

- Open access: articles freely available online

- High visibility within the field

- Retaining the copyright to your article

Submit your next manuscript at $\gg$ springeropen.com 